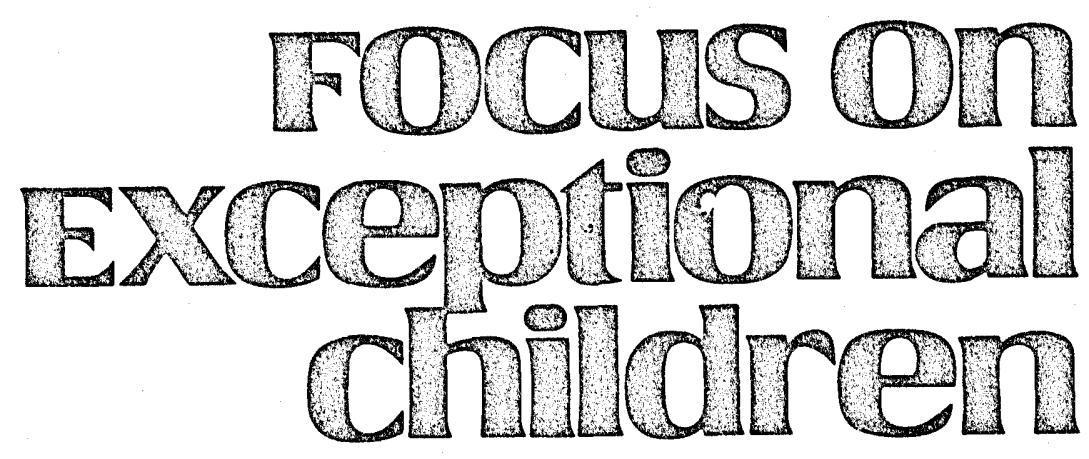

\title{
The Regular Education Initiative: A Concerned Response
}

\section{Harold W. Heller and Jeffrey Schilit}

On January 23, 1987, a meeting was held at Florida Atlantic University, Boca Raton, by a group of concerned professionals who came together to examine the federal government's initiative to make "educating students with special needs a shared responsibility" (called the Regular Education Initiative of the Office of Special Education and Rehabilitative Services, U.S. Department of Education). The purposes of this meeting were:

-to develop a perspective on the meaning and implications of this initiative; and

- to prepare a statement that might serve as a basis for discussion and direction by the entire education community, including professionals and ancillary personnel at all levels of general education and categorical education, as well as parents, advocates, and the public.

In developing this perspective and this statement, participants at the January meeting sought to convey to the Assistant Secretary of Special Education and Rehabilitative Services, Madeline C. Will, its mutual commendation for her significant efforts to bring about improved instructional options for students with special needs in America's public schools, as well as to register concern regarding the regular education initiative she advocated as an instructional imperative.

\section{DEFINITION}

The federal government's initiative is an effort to review, improve, and coordinate instruction for students whose learning and behavioral variance can be successfully addressed within general education classrooms. As stated in the Assistant Secretary's November, 1986, Report to the Secretary of Education:

The Office of Special Education and Rehabilitative Services is committed to increasing the educational success of children with learning problems. OSERS challenges States to renew their commitment to serve these children effectively. The heart of this commitment is the search for ways to serve as many of these children as possible in the regular classroom by encouraging special education and other special programs to form a partnership with regular education. The objective of the partnership for special education and the other special programs is to use their knowledge and expertise to support regular education in educating children with learning problems. (p. 20)

See p. 7 for another article, "Effective Teaching Strategies Used with the Mildly Handicapped in the Mainstream."
Dr. Heller is Dean of the College of Education and Applied Professions, University of North Carolina at Charlotte. Dr. Schilit is Chairperson of the Department of Exceptional Student Education, Florida Atlantic University, Boca Raton.

(C) Love Publishing Company, 1987. 


\section{STUDENTS ADDRESSED BY THE INITIATIVE}

The federal initiative encompasses a target population of students whose learning and behavior patterns vary from the general education norm but who might appropriately be educated in the general education classroom. These diverse students with special needs may vary from the norm in terms of:

-mild speech or language impairment;

-mild specific learning disability;

-mild mental retardation;

-mild behavior disorder or emotional disturbance;

- sensory impairment;

-physical impairment;

-disadvantaged or migrant socioeconomic status;

- limited English proficiency;

-need for remediation in one or more subject or skill areas;

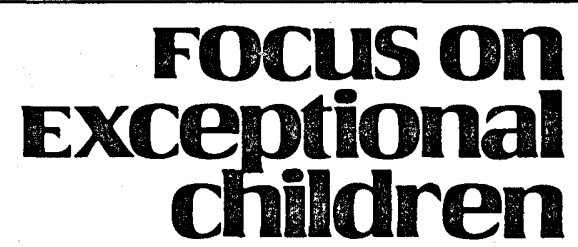

FOCUS ON EXCEPTIONAL CHILDREN (ISSN0015-511X) (USPS 203-360) is published monthly except June, July, and August as a service to teachers, special educators, curriculum specialists, administrators, and those concerned with the special education of exceptional children. This publication is annotated and indexed by the ERIC Clearinghouse on Handicapped and Gifted Children for publication in the monthly Current Index to Journals in Education (CIJE) and the quarterly index, Exceptional Child Education Resources (ECER). It is also available in microform from Xerox University Microfilm, Ann Arbor, MI. Subscription rates: Individuals, $\$ 24$ per year; institutions, $\$ 30$ per year. Copyright - 1987, Love Publishing Company. All rights reserved. Reproduction in whole or part without written permission is prohibited. Printed in the United States of America. Second class postage is paid at Denver, Colorado.

POSTMASTER: Send address changes to:

Love Publishing Company

Executive and Editorial Office

1777 South Bellaire Street

Denver, Colorado 80222

Telephone (303) 757-2579

EDITORIAL BOARD

Edward L. Meyen

University of Kansas

Richard J. Whelan

University of Kansas Medical Center

Stanley F. Love

Publisher
Carolyn Acheson Senior Editor
- sociocultural consequences, such as family disruption, substance abuse, teenage pregnancy; and

- pre-diagnostic variance suggesting risk of functioning within the lower half of the performance curve, risk of academic failure, risk of failure to develop adaptive behaviors, or risk of dropping out of school.

Any student who demonstrates a need for educational interventions and assistance beyond the capacity of general education (as augmented by consultive, technical, curricular, administrative, diagnostic, and therapeutic support and modification) is eligible for other instructional options in a continuum of specialized services, at the level and intensity indicated by the student's individualized education program (IEP).

\section{ASSUMPTIONS ON WHICH THE INITIATIVE IS BASED}

The Boca Raton participants endorsed the following assumptions associated with the federal initiative and issued a call for the educational community's endorsement and mutual efforts to ensure the conditions and requisites necessary to support these assumptions. If the condition(s), given below these assumptions are not met, the assumption is violated and optimal educational benefits will be impaired or unrealized. Unless efforts are made to guarantee the fulfillment of these conditions, educational opportunities for students with special needs will not be improved.

\section{STATEMENT OF OWNERSHIP AND} CIRCulation

Date of Filing: September 30, 1987

Title of Publication: FOCUS ON EXCEPTIONAL CHILDREN

Frequency of Issue: Monthly except June, July, and August

Location of Known Office of Publication: 1777 S. Bellaire St., Denver, CO 80222

Location of Headquarters of Publisher: 1777 S. Bellaire St., Denver, CO 80222

Name and Address of Publisher, Editor, and Managing Editor: Stanley F. Love,

1777 S. Bellaire St., Denver, CO 80222

Owner: Stanley F. Love

Extent and Nature of Circulation:

$\begin{array}{lcr} & \begin{array}{c}\text { Average No. Copies } \\ \text { Each Issue during } \\ \text { Preceding 12 Months }\end{array} & \begin{array}{c}\text { Single Issue } \\ \text { Nearest to } \\ \text { Filing Date }\end{array} \\ \text { Total No. Copies Printed } & 3,480 & 3,000 \\ \text { Paid Circulation } & 0 & 0 \\ \quad \text { Sales through Dealers, etc. } & 2,652 & 2,320 \\ \quad \text { Mail Subscriptions } & 2,652 & 2,320 \\ \text { Total Paid Circulation } & 250 & 200 \\ \text { Free Distribution } & 2,902 & 2,520 \\ \text { Total Distribution } & 578 & 480 \\ \text { Office Use and Left Over } & 3,480 & 3,000 \\ \text { Total } & & \end{array}$

1 certify that the statements made by me above are correct and complete. 


\section{Assumption 1: Student Rights}

The effort to make education for students with special needs a shared responsibility can take place without changing student rights and parent rights that are guaranteed in Public Law 94-142, Chapter I, and other state and federal laws.

It is assumed that there can be rights without labels and that the linkage of students, personnel, resources, and program will enhance opportunities and possibilities open to students in the target population, rather than limiting their access to individualized instruction, due process, and other protections that are currently their rights.

\section{Assumption 2: Support From The Education Community}

Support for making education for students with special needs a shared responsibility comes from general education, from all specialized areas of education, from higher education, and from parents of all children.

This assumption rests on the contingencies that:

- support is demonstrated in the allocation and assignment of fiscal, programmatic, personnel, and material resources and revision, and by leadership and involvement by all levels and areas of the education community.

- the leadership and involvement of parents is assured, not only of parents of students whose learning and behavior patterns vary from the general education norm, but also of parents of students whose learning and behavior are at or above the general education norm.

\section{Assumption 3: Partnership}

In order to improve the quality of instruction for students in the target population, general education, specialized areas of education, and support services will join in partnership.

Partnerships can and will occur if:

- the structures of school organization and bureaucracy are changed to enable the linkage of personnel and programs, new dimensions of instructional leadership and support, and the incorporation of values involving individualization and appreciation of the individual, which are inherent in providing education for students whose learning and behavior vary from the general education norms.
- the motivation of general education teachers to meet the needs of divergent classroom groups is enhanced by changes in school organization that promote collegiality, teacher collaboration and mutual support, meaningful professional and personal development, reinforcement and recognition of instructional achievement, and full participation in school and classroom decision making.

-the evaluation of teachers (and teaching) is based upon criteria other than pre- and post-test achievement test changes.

-inservice and preservice personnel preparation programs emphasize skills and knowledge in teamwork across general education, special education, the social sciences, and related human services programs.

\section{Assumption 4: Attitudes}

Students in the target population who are appropriately placed in general education classrooms are those who are able to perform socially, academically, and behaviorally in general education without experiencing social, academic, or behavioral stigmatization and isolation in that setting.

This assumption depends on appropriate attitudes on the part of personnel, students, and parents toward students whose learning and behavior patterns do indeed vary from the general education norm.

\section{Assumption 5: Student Grouping}

Students in the target population can be grouped together for instruction in general education classrooms with students who achieve at or above the average.

This assumption relies upon the conditions that:

- general education instruction addresses individual learning and behavioral needs of students in the target population.

-an array of supportive, specialized, and collaborative services is provided for general education teachers and for students in the target population.

-educators and parents are assured that increased diversity in instructional groups will not hinder the learning and achievement of any students.

-the building principal and other administrative personnel serve as instructional leaders and are intimately involved in the effort to improve and coordinate instruction for students whose learning and behavioral variance can successfully be addressed within general education classrooms. 
-fiscal resources are not merged but, rather, linked through cross-funding or split-funding so that categorical funds intended to support the education of various students with special needs remain targeted for these purposes. This can be accomplished not by waiving or changing regulations but, rather, by using procedures that account for collaborative personnel services in percents of full-time equivalency, according to division of personnel assignment among services and students.

\section{Assumption 6: Curriculum}

The curriculum of general education is appropriate for students whose learning and behavior patterns encompass $a$ wide range of variance.

Contingencies underlying this assumption are that:

- diverse curricula are available for students with divergent goals, objectives, needs, characteristics, and learning styles.

- teachers and specialists are able to modify curricula to meet the needs of the diversity of students whose learning and behavior patterns vary from the general education norm.

-inservice and preservice personnel preparation programs emphasize skills in and knowledge of the scope and sequence of many alternative curricula for students in the target population, as well as the scope and sequence of the general education curriculum.

\section{Assumption 7: Instruction}

The instructional methodologies of general education teachers are appropriate for students whose learning and behavior patterns vary from the general education norm.

Conditions requisite to this assumption are that:

- a wide range of instructional methods, options, and materials is used in the school district and is available in general education classrooms.

-teachers have repertoires of response styles and instructional approaches to match a variety of learning styles, learning rates, learning readiness, learning impediments, behavioral patterns, motivational differences, cultural and linguistic differences, individual strengths and weaknesses.

-responsible staff in each school plays a key role in curriculum, instruction, and staff development.

- the assessment of teacher effectiveness is an integral component of the shared responsibility for educating students with special needs.

-inservice and preservice personnel preparation programs emphasize skills and knowledge in a wide variety of response styles and instructional approaches for educating students whose learning and behavioral patterns vary from the general education norm.

\section{Assumption 8: Classroom Structure}

Restructuring of the general education classroom is vital in meeting the needs of students whose learning and behavioral patterns vary from the general education norm.

This assumption indicates that a restructuring of the general education classroom will accommodate:

-increased use of instructional aides.

-decreased adult-student ratio.

- greater varieties and levels of learning materials within each classroom.

-changes in school scheduling.

-mechanisms for collaborative teaching and learning.

- mechanisms for the delivery of specialized services in appropriate modes and settings.

\section{Assumption 9: Assessment}

Erroneous identification or nonidentification of students can be minimized.

The conditions supporting this assumption are that:

-shared decision making and collaborative teamwork occur among general education and specialized education programs at the pre-referral level to provide alternative interventions for students who are at risk of functioning within the lower half of the performance curve, at risk of academic failure, at risk of failure to develop adaptive behaviors, or at risk of dropping out of school.

- broader and better instructional programming is provided for students in need of remediation who are currently not eligible for specialized services and whose numbers have consequently inflated the count of handicapped students, particularly the count of learning disabled students.

-intensified research and development efforts are directed toward greater precision in instructionally relevant psychometric assessment, improved psychometric instruments and procedures, and alternative forms of assessment for purposes of improved curricula, instruction, student grouping, and classroom structure. 
-closer partnerships are developed among school psychology, education, and clinical psychology in preservice personnel preparation, and higher education programs emphasize the psychometric and data analytic/interpretive skills of school psychology, and of educational diagnostic trainees and practitioners.

\section{EXPERIMENTATION, REPLICATION, AND IMPLEMENTATION}

Assuming support from all levels of the American educational community, the logical next step in testing the feasibility of the federal initiative is to conduct experimental trials, as the Assistant Secretary has recommended, and as various states and school districts are proceeding to do. Currently recommended alternatives and combinations of these alternatives should be experimentally examined over time, and new alternatives should be developed and tested.

Part of each experimental trial must be to describe and evaluate, as precisely as possible, the learning, behavioral, and other salient attributes of students with whom various alternatives will work and will not work. Funding for the experimental study and development of alternative models should not come from other existing programs and priorities without extensive input from a national task force that fully represents all aspects of the American education community or from a large field survey that is fully representative.

When reasonable alternatives have been suggested through experimental trials, they must be field-tested extensively with children and teachers in many classrooms in many, diverse geographic, administrative, and educational settings and levels so as to:

-establish minimum standards for replication, or the essential elements of each model that must be replicated with fidelity in order to preserve the procedural and philosophical intent of the model;

- establish antecedent conditions necessary for implementing various models in diverse geographic, administrative, and educational settings and levels;

- establish and maintain procedures and processes for forecasting manpower resource needs requisite for staffing various models and implementation strategies; and

-derive specific information on each model's attributes and requirements so that adopters can be assisted in the essential task of matching various possible practices with local conditions, characteristics, and contexts.

Eventual widespread implementation of alternative models must be preceded and accompanied by: -careful application of the principles of planned change.

-appropriate inservice and preservice preparation for personnel at all levels of the educational community; and

-post-training evaluation of personnel effectiveness and program effectiveness.

In a change of the magnitude suggested by the federal initiative, and in consideration of the enormous variations among schools' and districts' characteristics, conditions, and contexts, it is of paramount importance that the initiative be tested and ultimately carried out with the implicit understanding that every school is an experiment, that every school will have to recognize individuality in order to succeed in implementing the changes that are called for.

\section{NECESSARY CHANGES IN SCHOOL ORGANIZATION}

Many efforts to improve education have failed to take root, or to bring about substantial change, or to continue to develop over time, primarily because of a failure of the reformers to recognize the nature of school organization and its constancy as a bureaucratic structure. Certain structures of school organization and the internal strengths of the school bureaucracy itself make certain things more possible and more likely to occur, and other things less possible and less likely to occur.

The Boca Raton participants agreed that a great need exists to determine whether it is literally possible to extend the goals of the federal initiative, beyond the stage of small federally funded experiments, within the current value systems and conditions that characterize school organization. The concerned special educators at Boca Raton emphasized that there is a real need to determine whether current structures of school organization can be changed in order to make such an initiative as far-reaching as that proposed possible for widespread implementation. Among the crucial factors to be considered are the values of the people who work inside the school bureaucracy, how school organization influences school culture and values, and the degree to which any particular innovation contradicts these values.

Perhaps a major benefit of Public Law 94-142 has been that people with special education's values concerning the uniqueness and potentials of the individual have been able to move into positions of greater influence within the schools. Among the positive outcomes of Public Law 94-142 may not just be the mainstreaming of special education students but also the greater sensitization of regular educators to the motives and purposes of special educators. 
In examining the pursuit of the regular education initiative to make the education of students with special needs a shared responsibility, the Boca Raton participants agreed that it is important to acknowledge that special education cannot seek institutional solutions to individual problems without changing the nature of the institution. This, in turn, may be the major message of the Assistant Secretary's initiative-that the nature of school organization is what must fundamentally change. Otherwise the outcome may be programs that work in $5 \%$ of the schools, fail in $95 \%$ of the schools, and are eventually abandoned, along with the hopes of students with special needs, their teachers, and their parents. Prevention of the latter requires an initiative that involves the regular education partner in the dialogue as a primary architect and not merely as the recipient of a well intended action. Without the latter, the highly laudable "challenge and commitment" position of the Office of Special Education and Rehabilitative Services will be of miniscule value because that challenge and commitment is not shared with equal enthusiasm by regular education.

\section{BOCA RATON CONFERENCE PARTICIPANTS}

$\begin{array}{ll}\begin{array}{l}\text { Kathrine Morsink } \\ \text { University of Florida }\end{array} & \begin{array}{l}\text { James Chalfant } \\ \text { University of Arizona }\end{array} \\ \begin{array}{l}\text { Deborah Smith } \\ \text { University of New Mexico }\end{array} & \begin{array}{l}\text { Jeanne McCarthy } \\ \text { University of Arizona }\end{array} \\ \begin{array}{l}\text { Jeptha Greer } \\ \text { Council for Exceptional Children }\end{array} & \begin{array}{l}\text { Dvenna Duncan } \\ \text { University of Portland }\end{array}\end{array}$

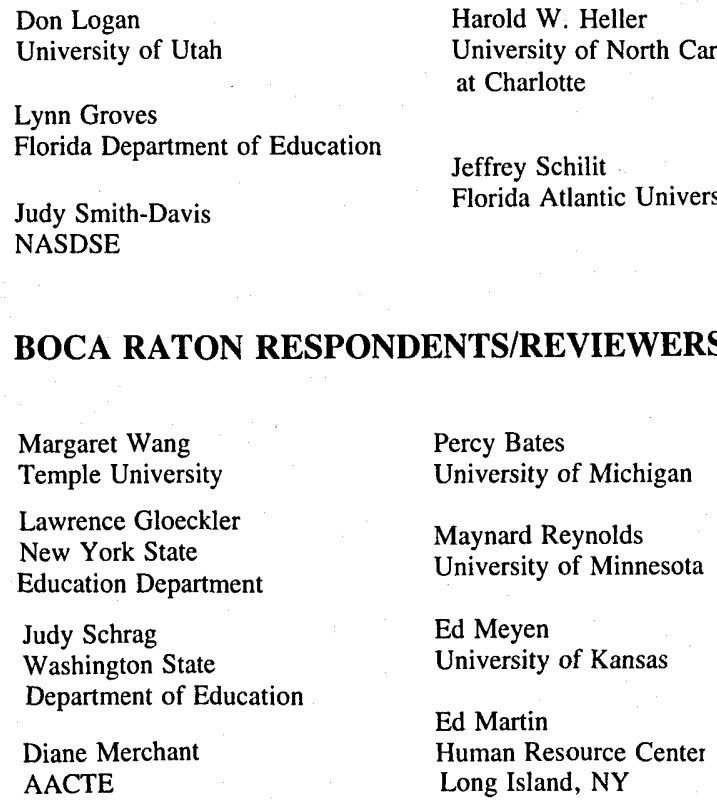

Phil Burke

University of Maryland

\section{REFERENCE}

*Persons receiving and reviewing materials generated from the Conference working session.

\section{professional update}

\section{NEW BOOK}

\section{Curriculum Decision Making for Students With Severe Handicaps: Policy and Practice}

\section{by Dianne L. Ferguson}

Curriculum for the severely handicapped is still an emerging area, in the midst of rapid change. This book explores the transition brought about by the Education for All Handicapped Children Act, where it has taken these students, and where they are going. One chapter, for example, discus- ses "functional teaching," with students classified for teaching purposes as "walkers and talkers," "walkers," "behavior kids," and "wheelchair kids." Other chapters focus on curricular choices, translating policy into practice, teacher preparation, specialization of content, increasing professionalization, and other timely issues.

This book provides a thoughtful investigation on program planning and suggests ways in which special education might contribute to broader educational reform. The author's tone is progressive and insightful.

Published by Teachers College Press, Columbia University, New York, the book is a 170-page paperback. 


\title{
Effective Teaching Strategies Used with the Mildly Handicapped in the Mainstream
}

\author{
Mary E. Franklin, Elaine Little, and James A. Teska
}

Recent reports to Congress revealed that an increasingly high percentage of the handicapped population consists of children who are mildly handicapped and are receiving instruction in the mainstream (U.S. Department of Education $1984,1985)$. The most common service delivery model used with mildly handicapped children in regular education is based on a "pull-out" system (Hagerty \& Abramson, 1987), despite the increasing volume of research to the contrary (Chalfant, 1984; Englert, 1984; Hersh \& Walker, 1983; Wang \& Reynolds, 1985).

Researchers and educational decision makers involved in excellence in education are investigating total integration of mildly handicapped students in regular education (Hagerty \& Abramson, 1987; Sontag, Hagerty, \& Button, 1983; U.S. Department of Education, 1985). In support of this concept, Gerber (1984) urges improvement in regular education programs in an attempt to more appropriately meet the needs of these students. Adapting teaching strategies within the regular classroom can provide the necessary adjustment mildly handicapped students need to succeed in the mainstream (Will, 1984; Wood, 1984).

Hagerty and Abramson (1987) defined mildly handicapped students as "a heterogeneous group whose shared characteristic is their inability to fully benefit from the existing regular education system" (p. 316). Existing instructional intervention strategies, if implemented by regular educators, may enhance the learning of mildly handicapped students in regular education. Because handicapped students receive most of their instruction at the regular class level, interventions by regular classroom teachers must be delivered at that level.

This article explores evidence of the benefits and limitations of four selected teaching strategies-direct instruction, classroom management, cooperative grouping, and metacognition-that may facilitate successful integration of mildly handicapped children in the mainstream. The focus is on empirical research on mildly handicapped children, for whom these strategies are intended to create effective learning environments in the mainstream.

\footnotetext{
Mary Franklin is affiliated with the Department of Early Childhood and Special Education, University of Cincinnati. Elaine Little and James Teska are on the faculty at Southern Illinois University.
}

Effective teaching strategies are more than common-sense approaches to teaching. They are based on a collection of research practices that are clearly defined, demonstrated, and mastered (Peter \& Lloyd, 1986). Research on effective teaching strategies in both regular and special education has consistently demonstrated that the way in which teachers deliver instruction affects student achievement. Anderson, Everston and Brophy (1979), Becker (1977), Englert (1984), Good (1979), Good and Grouws (1979), Rosenshine (1979), and Stallings (1980) have all indicated that training teachers in effective teaching strategies is positively associated with student achievement. As examples, teacher behavior in conducting daily review of either homework or mental computations, demonstrating the new skill and asking many questions in a direct, businesslike manner, and monitoring and checking seatwork and homework have been shown to lead to higher student achievement and higher academic learning time (ALT).

Academic learning time can be defined as time spent actively engaged in work that typically produces a higher rate of success. The use of classroom time is controlled by teachers. They should engineer ALT to maximize students' learning, taking care to not waste learning time on nonacademic procedures such as taking roll, explaining directions, or giving permission to leave the room.

\section{DIRECT INSTRUCTION}

Results from studies in direct instruction suggest that successful teachers maintain a strong academic focus and spend less time in nonacademic activities. Researchers Stallings and Kaskowitz (1974) found a positive relationship between the amount of time a student spent on activities involving reading or mathematics and academic gain, whereas a student involved in other activities such as group time, stories, arts and crafts produced a negative relationship in academic gain. Similar results were noted relative to types of instructional materials used; textbooks, workbooks, and instructional worksheets yielded positive results in academic gain, while the use of toys, puzzles, and even academic games always produced negative findings in academic gain.

In a study comparing the effects of formal and informal styles of instruction, Bennett (1976) found that students in 
formal classrooms showed the highest achievement in reading and mathematics. Teachers of the formal classrooms emphasized regular homework assignments, administered weekly tests, marked and graded students' work, and expected students to be quiet.

Classrooms that were organized to give students a great deal of flexibility in the direction of their own activities yielded negative results. Studies relative to grouping for instruction indicated that classes in which teachers worked with one or two students at a time did not produce significant gains in achievement, whereas classes in which teachers who worked with small groups composed of three to seven students or more produced significant achievement gains (Englert, 1984; Rosenshine, 1980; Stallings \& Kaskowitz, 1974).

\section{CLASSROOM MANAGEMENT}

Managing a classroom is an essential component of teaching success. Researchers of effective teaching have concluded that classroom management skills are associated not only with student attention and time on task but also with student achievement in basic skills. Brophy (1979), Englert (1984), Good (1979), and Rosenshine (1979) have all stated that teaching organization and classroom management create effective learning environments. Teachers' ability to manage a classroom involves planning, organizing, and maintaining a learning environment that engages students in productive activities, thus lessening the need to deal with behavior problems.

Kounin (1970) demonstrated the importance of classroom management by comparing two teachers. The first teacher was considered an effective classroom manager. Students were attentively engaged in seatwork. Transitions between activities were brief and orderly. The second teacher seemed exasperated and barely able to keep things together. Students were inattentive, and transitions were lengthy and chaotic. Much of the teacher's time was spent handling student misconduct.

Kounin videotaped each teacher interacting with the students and found no systematic differences at all, although the author had expected to find large and systematic differences in methods of handling misconduct. It was noticed, however, that the teachers did differ in other ways, particularly in their systematic approach to minimizing the frequency with which students became disruptive in the first place. Kounin suggested that an effective classroom manager should: -nip the problem in the bud before it escalates into disruption.

-learn to do several things at one time.

-move through the activity at an appropriate pace so students will not become stagnated and bored.

In addition, effective classroom management establishes routines in which information is introduced gradually as needed, without overloading students with too much at one time. Implementing classroom rules and procedures is a matter of instruction rather than "control," although following through on stated expectations is important. Effective managers not only tell their students what they expect of them, but they actually model the desired procedures, take time to answer students' questions, and allow time to practice some procedures (Englert, 1984; Kounin, 1970).

\section{COOPERATIVE GROUPING}

Grouping students for instruction is a common educational practice. Grouping patterns are related to student achievement and are major characteristics of the school learning climate. When working with a heterogeneous group such as the mildly handicapped, cooperative grouping must be considered. This form of grouping places students of different demonstrated achievement levels together. Using this strategy, teachers structure the class so that students work together to achieve a shared academic goal. Students are therefore accountable not only for their own achievement but also for the performance of others, because the group's evaluation is based on its product (Schneidewind \& Salind, 1987).

Cooperative grouping offers two distinct advantages:

1. Groups practicing for competition generally spend all their valuable time working diligently to learn the material.

2. While groups are actively engaged in their task, a teacher has more time to focus on individuals who may need help.

Research on cooperative learning provides evidence that this strategy improves the academic learning climate and overall student achievement in school. Slavin and DeVries (1978) noted improvements in race relations, attitudes toward school, and increased academic learning time. Other researchers (Gunderson \& Johnson, 1978; Johnson, Johnson \& Anderson, 1978) indicated that some cooperative strategies positively affect self-esteem. 


\section{METACOGNITION}

Metacognitive strategies aid underachievers in directing their own activities. This practice has proven successful with students who are inattentive and do not persevere on a given task.

Flavell (1976) and Brown (1978) distinguish between knowledge (cognition) and an understanding of that knowledge (metacognition). Metacognition is one's knowledge about one's own cognitive processes and products and anything related to them. For example, the use of metacognitive strategies helps a person to:

-recognize that he or she is having more trouble learning one thing than another.

-check and double-check a fact before accepting it.

-recognize that alternatives are available.

-realize that writing a note is sometimes necessary to avoid forgetting the information.

According to Brown (1978), metacognitive strategies are what we have traditionally referred to in education as "study skills." Metacognitive variables such as predicting, planning, checking, and monitoring give students knowledge of functioning that leads to both greater understanding and more time on task.

Palincsar (1987) described a procedure called "reciprocal teaching," involving dialogue between teachers (including peer teachers and teacher aides) and students for the purpose of teaching reading comprehension. Prior to the intervention, students in the experimental group, who were pretested on a standardized comprehension test, earned scores below the 20 th percentile. At the end of 20 days of reciprocal teaching, the experimental students were post-tested; at that time they earned scores at the 50th percentile and above. Students who participated in the study stated that they learned what reading was all about, to take their time, and what to do while reading.

Strong empirical evidence supports the effectiveness of metacognition in enhancing reading comprehension. Wong and Jones (1982) taught students with learning problems to identify the main idea and generate questions pertaining to their reading. Evidence of successful teaching of summarization to improve comprehension has been provided by several authors (Baumann, 1986; Day, 1980; Hare \& Borchardt, 1984). Research evaluating metacognitive strategy instruction suggests that students can achieve when provided explicit instruction regarding efficient strategies to follow. Learners who are informed of the purpose and consequences of these strategies gradually retain the control of the application.

\section{CONCLUSION}

Given that the U.S. Department of Education's Annual Report to Congress indicates 1) that mildly handicapped students comprise over $90 \%$ of the handicapped population, and 2) that an extremely high percentage of these children receive services mainly in the regular classroom, improvements in instructional effectiveness found in regular education environments should logically yield significant benefits in the academic performance and socialization of mildly handicapped students. (Hagerty \& Abramson, 1987, p. 317)

Improvements in instructional effectiveness, such as the teaching strategies discussed (direct instruction, classroom management, cooperative grouping, and metacognition) are a select few of the strategies needed to successfully facilitate mainstreaming. Any effective teacher can use these strategies, whether teaching handicapped children or nonhandicapped children. Knowledge of these and other teaching strategies can serve as a frame of reference, creating a base from which to operate. With a clear understanding of teaching strategies such as those presented here, regular educators' feelings of inadequacy about working with handicapped children will diminish.

Results from the literature on teaching strategies are promising, but the need for additional research has been clearly identified. Of central importance is a need to explore the matching of students' learning styles to direct instruction and classroom management. Although the present review on direct instruction indicates its effectiveness in academic areas, it remains inconclusive in nonacademic areas. Along similar lines, as laudable as it may seem to offer choices to students, an examination of the value of allowing students to work on individualized assignments, including choice of time, sequence for doing prescribed activities, and choice of behavior (e.g., where to work, when to leave one's seat), were not favorable in terms of academic engaged time.

Evidence on classroom management suggests that formal classroom instruction yields more productivity than does informal classroom instruction (Bennett, 1976; Brophy, 1979; Good, 1979). Additional studies are needed on teaching styles, particularly examining engaged minutes. These studies should attempt to determine the possible causes for different engagement in different settings. Developing or identifying engaging materials is another topic for study. Some of the readers, textbooks, workboxes, and workbooks that students use during seatwork are probably more used than others, but little is known about their engaging characteristics.

Cooperative group learning can improve the effectiveness of a class or school program significantly and reduce the amount of time required for some students to master grade- 
level skills. Working together in a group has been found to reflect and influence the school staff's expectations of the various student groups. Students come to accept these expectations and evaluations of their learning potential, and to perform at the expected level. Group learning is suggested for the entire school social system, to be used by all teachers. Although additional research has to be done on the total effects of group learning, it does seem to be a valuable tool. But, like all tools, it must be implemented correctly to produce the desired results.

Metacognitive strategies have been shown to be productive in teaching reading skills (Baumann, 1986; Day, 1980; Hare \& Borchardt, 1984; Wong \& Jones, 1982) and problem-solving skills (Flavell, 1976; Karnes, Johnson, Cohen, \& Beauchamp, 1986) to handicapped and nonhandicapped students. Conversely, some research has indicated a deficiency in metacognitive sophistication with learning disabled students (Wong, 1982; Garner, 1980). This research demonstrated that LD students are not adept at regulating their cognition. From the information provided here on metacognition, continued investigation is recommended on handicapped students' ability to apply metacognitive strategies in a variety of academic and nonacademic areas.

In conclusion, this article looked only at the instructional aspect. Some believe that the success of mainstreaming rests not on techniques but on attitudes. It is recognized, however, that many factors-human resources, politics, administration, and parents-influence the success of mainstreaming.

The need to change regular educators' attitudes toward educating handicapped students has generated much talk. It will be difficult to accomplish as long as teachers remain unaware that teaching strategies used with regular education students are sometimes the same as those used with handicapped students.

There is no single "best" approach to mainstreaming, but a basic knowledge of various teaching strategies can ease the anxieties and frustrations that often accompany mainstreaming, for both regular and special education teachers. Cooperative planning between the two groups is extremely important for the success and implementation of instructional plans for handicapped students.

\section{REFERENCES}

Anderson, L., Everston, C., \& Brophy, J. (1979). An experimental study of effective teaching in first grade reading groups. Elementary School Journal, 79, 193-223.
Baumann, J.F. (1986). The effectiveness of a direct instruction paradigm for teaching main idea comprehension. Reading Research Quarterly, 20, 93-108.

Becker, W. (1977). Teaching reading and language to the disadvantagedwhat we have learned from field research. Harvard Education Review, 47, 518-543.

Bennett, N. (1976). Teaching styles and pupil progress. Cambridge, MA: Harvard University Press.

Brophy, J. (1979). Teacher behavior and its effects. Journal of Educational Psychology, 11, 733-750.

Brown, A.L. (1978). Knowing when, where, and how to remember: A problem of metacognition. In R. Glaser (Ed.), Advances in instructional psychology. Hillsdale, NJ: Lawrence Erlbaum Assoc.

Chalfant, J. (1984). Identifying learning disabled students: Guidelines for decision making. Burlington, VT: Northeast Regional Resource Center.

Day, J.D. (1980). Training summarization skills: A comparison of teaching methods. Doctoral dissertation, University of Illinois, Urbana.

Englert, C.S. (1984). Measuring teacher effectiveness from the teacher's point of view. Focus on Exceptional Children, 17, 1-15.

Flavell, G.H. (1976). Metacognitive aspects of problem solving. In L.B. Resnick (Ed.), The nature of intelligence (pp. 231-235). Hillsdale, NJ: Lawrence Erlbaum Assoc.

Garner, R. (1980). Monitoring of understanding: An investigation of good and poor readers' awareness of induced miscomprehension of text. Journal of Reading Behavior, 12, 55-63.

Gerber, M.M. (1984). The Department of Education's sixth annual report to Congress on P.L. 94-142: Is Congress getting the full story? Exceptional Children, 51, 209-224.

Good, T.L. (1979). Teacher effectiveness is the elementary school: What we know about it now. Journal of Teacher Education, 30, 32-64.

Good, T.L., \& Grouws, D. (1979). The Missouri mathematical effectiveness project: An experimental study in a fourth grade classroom. Journal of Educational Psychology, 71, 335-362.

Gunderson, B., \& Johnson, D.W. (1978). Using cooperative learning in French classes. Doctoral dissertation, University of Minnesota, Minneapolis.

Hagerty, G.J., \& Abramson, M. (1987). Impediments to implementing national policy change for mildly handicapped students. Exceptional Children, 53, 315-324.

Hare, V.G., \& Borchardt, K. (1984). Direct instruction of summarization skills. Reading Research Quarterly, 20, 62-78.

Hersh, R., \& Walker, H. (1983). Great expectations: Making school effective for all students. Policy Studies Review, 2, 147-188.

Johnson, D.W., Johnson, R., \& Anderson, D. (1978). Relationship between student cooperative, competitive, and individualistic attitudes and attitudes toward schooling. Journal of Psychology, 100, 183-199.

Karnes, M.B., Johnson, L.J., Cohen, T., \& Beauchamp, A. (1986). Facilitating school success among mildly and moderately handicapped children by enhancing task persistence. Journal of the Division of Early Childhood, 9, 151-161.

Kounin, J. (1970). Discipline and group management in classrooms. New York: Holt, Rinehart \& Winston.

Palincsar, A. (1987). Metacognitive strategy instruction. Exceptional Children, 53, 118-124.

Peter, E., \& Lloyd, J. (1986). Effective instruction: Critical components of teaching. Teaching Exceptional Children, 19, 46-47.

Rosenshine, B. (1979). Content, time and direct instruction. In P.L. Peterson \& H.J. Walberg (Eds.), Research on teaching: Concepts, findings, and implications. Berkeley, CA: McCutchan Publishing.

Rosenshine, B. (1980). How time is spent in elementary classrooms. In C. Denham \& A. Lieberman (Eds.), Time to learn. Washington, DC: National Institute of Education. 
Slavin, R., \& DeVries, D.L. (1978). Learning teams. In H. Walberg (Ed.), Educational environments and effects: Evaluation, policy and productivity. Berkeley, CA: McCutchan Publishing.

Schneidewind, N., \& Salind, S.J. (1987). Cooperative working. Teaching Exceptional Children, 19, 22-25.

Sontag, E., Hagerty, G., \& Button, J. (1983). Perspectives on the status and future of special education and regular education. In M.C. Reynolds (Ed.), The future of mainstreaming (pp. 65-73). Washington, DC: AACTE Publications.

Stallings, J. (1980). Allocated academic learning time revisited or beyond time on task. Educational Researcher, 9, 11-16.

Stallings, J.A., \& Kaskowitz, D.H. (1974). Follow through classroom observation evaluation 1972-73. Menlo Park, CA: Stanford Research Institute.

U.S. Department of Education. (1984). Annual report to Congress on the implementation of the Education of the Handicapped Act. Washington, DC: U.S. Government Printing Office.
U.S. Department of Education. (1985). Annual report to Congress on the implementation of the Education of Handicapped Act. Washington, DC: U.S. Government Printing Office.

Wang, M., \& Reynolds, M. (1985). Avoiding the "catch 22" in special education reform. Exceptional Children, 51, 497-502.

Will, M.C. (1984). Let us pause and reflect-but not too long. Exceptional Children, 15, 11-16.

Wong, B. (1982). Strategic behavior in selecting retrieval cues in gifted, normally achieving and learning disabled children. Journal of Learning Disabilities, 15, 33-37.

Wong, B., \& Jones, W. (1982). Increasing metacomprehension in learning disabled and normally achieving students through self-question training. Learning Disability Quarterly, 5, 228-240.

Wood, J. (1984). Adapting instruction for the mainstream. Columbus, OH: Charles E. Merrill.

\section{Professional update}

\section{UPCOMING MEETINGS}

\section{November 1-3, 1987}

Early Childhood Conference on Children with Special Needs

Marriott City Center

Denver, Colorado

Contact: Council for Exceptional Children (703) $620-3660$

\section{November 9-14, 1987}

National Association for Gifted Children

Hyatt Regency Hotel

- New Orleans, Louisiana

Contact: NAGS (617) 784-3475

\section{November 13-16, 1987}

American Speech-Language-Hearing Association

The Rivergate

New Orleans, Louisiana

Contact: ASHA (301) 897-5700

\section{November 15-17, 1987}

National Conference on the Future of Special Education

Hyatt Orlando

Orlando, Florida

Contact: Council for Exceptional Children

(703) 620-3660

\section{NEW BOOKS}

\section{The Hearing Impaired: Birth to Six}

\section{by June Grant}

The author's extensive experience has been translated into this practical, useful guide in managing young children with hearing impairments. Among the premises are that the secondary language deficit is the most detrimental aspect of the handicap, the environment should approximate that of hearing children to acquire language naturallly, the optimal time to initiate intervention is within the first six months of life, residual hearing should be maximized, and the total environment and the profession must share the same expectations for the child. The author's orientation is oral-aural, although the content is applicable to programs using total communication or ASL. She emphasizes promoting the language facility in the way that serves the child best.

Other than the language component, the area of most emphasis in this book is that of early intervention, with parent/family involvement. The book covers a lot of ground in an informative, competent way, backed by research and experience.

The publisher of this 182-page paperback is College-Hill Press, San Diego. 


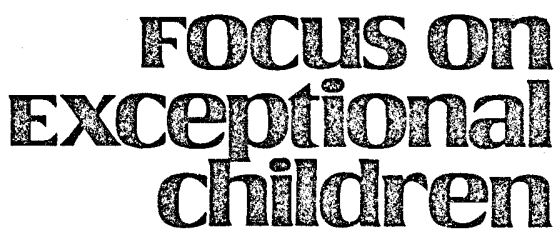

\section{Choices in Deafness: A Parents Guide}

\section{Edited by Sue Schwartz}

This new book presents a balanced discussion of the three predominant methodologies for teaching communication to hearing impaired children-cued speech, oral communication, and total communication-from the standpoint of the professional and the parent. It has received positive endorsements from the American Society for Deaf Children, the Alexander Graham Bell Association for the Deaf, and the National Cued Speech Association.
Many firsthand accounts and anecdotes make this book a pleasure to read and leave the reader with a positive, optimistic attitude. A reading list, audiovisual materials sources, directory of national service organizations, and addresses for state programs serving the hearing impaired all contribute to this book as a valuable resource. Practitioners would do well to bring it to the attention of families with hearing impaired members.

The publisher of this 216-page paperback is Woodbine House, 10400 Connecticut Avenue, Kensington, MD 20895.

\section{NEW STATISTICS ON EDUCATIONAL ENVIRONMENTS BY AGE GROUP Percent of Handicapped Children and Youth Served in Nine Educational Environments by Handicapping Condition During School Year 1984-85}

\begin{tabular}{lccccccccc}
\hline $\begin{array}{l}\text { Handicapping } \\
\text { Condition }\end{array}$ & $\begin{array}{c}\text { Regular } \\
\text { Class }\end{array}$ & $\begin{array}{c}\text { Resource } \\
\text { Room }\end{array}$ & $\begin{array}{c}\text { Separate } \\
\text { Class }\end{array}$ & $\begin{array}{c}\text { Public } \\
\text { Separate } \\
\text { Facility }\end{array}$ & $\begin{array}{c}\text { Private } \\
\text { Separate } \\
\text { Facility }\end{array}$ & $\begin{array}{c}\text { Public } \\
\text { Residential } \\
\text { Facility }\end{array}$ & $\begin{array}{c}\text { Private } \\
\text { Residential } \\
\text { Facility }\end{array}$ & $\begin{array}{c}\text { Correctional } \\
\text { Facility }\end{array}$ & $\begin{array}{c}\text { Homebound } \\
\text { Hospital } \\
\text { Facility }\end{array}$ \\
\hline $\begin{array}{l}\text { Learning } \\
\text { Disabled }\end{array}$ & 16.26 & 60.68 & 20.84 & 1.11 & 0.77 & 0.03 & 0.06 & 0.16 & 0.08 \\
$\begin{array}{l}\text { Speech or } \\
\text { Language } \\
\text { Impaired }\end{array}$ & 64.80 & 26.33 & 4.90 & 0.97 & 2.46 & 0.03 & 0.03 & 0.03 & 0.46 \\
$\begin{array}{l}\text { Mentally } \\
\text { Retarded }\end{array}$ & 4.80 & 28.83 & 52.37 & 8.29 & 2.10 & 2.52 & 0.40 & 0.19 & 0.50 \\
$\begin{array}{l}\text { Emotionally } \\
\text { Disturbed }\end{array}$ & 11.79 & 34.22 & 33.34 & 8.57 & 4.80 & 1.69 & 2.41 & 1.59 & 1.59 \\
$\begin{array}{l}\text { Hard of } \\
\begin{array}{l}\text { Hearing } \\
\text { and Deaf }\end{array}\end{array}$ & 21.03 & 23.49 & 31.03 & 7.23 & 4.83 & 10.67 & 1.09 & 0.10 & 0.53 \\
$\begin{array}{l}\text { Multihandi- } \\
\text { capped }\end{array}$ & 2.70 & 13.48 & 42.72 & 17.61 & 9.70 & 6.07 & 2.51 & 0.35 & 4.85 \\
$\begin{array}{l}\text { Orthopedically } \\
\text { Impaired }\end{array}$ & 18.27 & 20.62 & 33.42 & 12.99 & 5.50 & 0.80 & 0.72 & 0.03 & 7.65 \\
$\begin{array}{l}\text { Other Health } \\
\text { Impaired }\end{array}$ & 23.47 & 25.44 & 32.69 & 3.97 & 1.94 & 0.72 & 0.56 & 0.02 & 11.18 \\
$\begin{array}{l}\text { Visually } \\
\text { Handicapped }\end{array}$ & 32.55 & 29.55 & 18.80 & 4.05 & 3.25 & 9.80 & 1.04 & 0.21 & 0.74 \\
$\begin{array}{l}\text { Deaf-Blind } \\
\text { All Conditions }\end{array}$ & 26.73 & 41.61 & 23.76 & 3.47 & 2.08 & 0.95 & 0.39 & 0.25 & 0.75 \\
\hline
\end{tabular}

From Ninth Annual Report to Congress on the Implementation of the Education of the Handicapped Act, 1987, Washington, DC: U.S. Department of Education, p. 20. 